\title{
Bio efficacy of Selected Systemic and Non Systemic Fungicides invitro and invivo Condition against Banded Leaf and Sheath Blight Disease of Maize caused by Rhizoctonia solani Kühn
}

\author{
Bolla Venkateswarlu* and Surja Kanta Beura \\ Department of Plant Pathology, College of Agriculture, OUAT, \\ Bhubaneswar -751003, Odisha (India) \\ *Corresponding author
}

\section{A B S T R A C T}

Keywords

Banded leaf and sheath blight, Rhizoctonia solani Maize, Fungicides

Article Info

Accepted:

17 June 2020 Available Online: 10 July 2020
Ten fungicides were tested at different concentrations in in vitro and in vivo for the management of banded leaf and sheath blight of maize. Thiophanate methyl $70 \mathrm{WP}$, difenoconazole $25 \mathrm{EC}$, hexaconazole $5 \mathrm{EC}$ and validamycin 3 SL were screened against Rhizoctonia solani at 10, 15, 20 and $25 \mathrm{ppm}$ concentrations for their anti fungal activity. where, as mancozeb $75 \mathrm{WP}$, chlorothalonil $75 \mathrm{WP}$, zineb 75WP and captaf $50 \mathrm{WP}$ of the fungus at 100,200, 300 and $400 \mathrm{ppm}$ concentrations, respectively along with control. At10 percent concentration difenoconazole, thiophanate methyl, completely check the radial growth of the fungus. Based on effectiveness of fungicides in vitro, they were further tested under in vivo conditions. carbendazim 50 WP @ $0.1 \%$ applied as seed treatment followed by validamycin 3SLfoliar spray showed lower disease severity, highest grain yield followed by $2750 \mathrm{Kg} / \mathrm{ha} @ 0.2$ per cent.

\section{Introduction}

Maize (Zea mays L.) is one of the oldest cereals; which has been under cultivation for thousands of years. It is one of the most versatile emerging crops having wider adaptability under varied agro-climatic conditions. Globally, it is known as 'Queen of Cereals' because it has the highest genetic yield potentiality. In Odisha it is grown in many districts like Nabarangpur, Koraput,
Kalahandi, Mayurbhanj, Keonjhar, Jajpur and others. It covers an area of $0.25 \mathrm{~m}$. ha from which it can produces $0.754 \mathrm{~m} . t$ at a productivity of $3.03 \mathrm{t} \mathrm{ha}^{-1}$ in Odisha. Among the fungal diseases Banded Leaf and Sheath Blight disease at present is considered as a major setback in production of maize crop in the state. Dhillon and Prasanna (2001)have been reported that, about 13.2 per cent of the economic product of maize is estimates to be lost annually due to BLSB on maize. The first 
symptoms appear as sclerotia on the lower leaf. Thesclerotia mycelia may be upwards as vertical spread Ahuja and Payak (1992). The present study was conducted to bio efficacy of different systemic as well as non systemic fungicides for effective management of the disease.

\section{Materials and Methods}

Cultures of $R$ solani was isolated from naturally infected maize leaf,sheath and cob on PDA medium and then it was further purified by hyphal tip method and maintained on PDA in culture tubes at $28 \pm 1^{0} \mathrm{C}$ in BOD incubator for further studies

Described concentrations of fungicides were screened using poison food technique Vincent (1947). Stock solution of each fungicide was prepared by dissolving weighted quantity of fungicide in a measured volume of sterilized distilled water and adds to double strength sterilized PDA. The amount was calculated using following formula:

\section{$\mathrm{C} 1 \mathrm{~V} 1=\mathrm{C} 2 \mathrm{~V} 2$}

Where

$\mathrm{C} 1=$ Concentration of stock solution

$\mathrm{C} 2=$ Volume $(\mathrm{ml})$ of the of stock solution to be added

$\mathrm{V} 1=$ Desired concentration $(\mu \mathrm{g} / \mathrm{ml})$ and

$\mathrm{V} 2=$ Measured volume $(\mathrm{ml})$ of the medium

Medium amended with desired concentration of selected fungicides, four replications were maintained. After solidification of medium, the plates were centrally inoculated with 5 $\mathrm{mm}$ disc of the fungus cut from edge of a fully grown culture with the help of sterilized cork borer. Unamended PDA plates, inoculated with test pathogen, served as a control Lal, Butchaiah. and Baruah(1985). Four replications were maintained for each concentration of fungicide and incubated at
$28 \pm 1^{0} \mathrm{C}$. Experiment was conducted during Kharif seasons of 2015-16 and 2016-17 in RBD with three replication. Seeds of susceptible Vivek hybrid -43 was sown in plots $3 \times 2 \mathrm{~m}^{2}$ with $30 \mathrm{~cm}$ inter row spacing and $10 \mathrm{~cm}$ plant to plants.

Bhubaneswar is a hot spot for Banded Leaf and Sheath Blight (BLSB) disease. However, before the spray of fungicides, all the plots were artificially inoculated with mycelia /sclerotia fragments (10 ml / $1 \mathrm{~L}$ water) of $R$. solani one day before the fungicides spray.

On the basis of in vitro studies effective fungicides were used as seed treatment and foliar spray. The treatments include thiophanate methyl 70WP (0.1\%), difenoconazole 25EC(1.5\%), hexaconazole $5 \% \mathrm{EC}(2.0 \%)$ and validamycin 3\%SL (3.0 $\%)$. Mancozeb (0.3\%), chlorothalonil $75 \mathrm{WP}$ $(0.25 \%)$, zineb $75 \mathrm{WP}(0.15 \%)$ and captaf 50 WP $(0.1 \%)$ were used as foliar spray with seed treatment with carbndazimat $0.1 \%$ or $1 \mathrm{~g} / \mathrm{Kg}$ of seed. Chemicals were sprayed thrice at 10- day's interval staring from one and half month old crop. Disease severity was recorded on 5 rows of 100 no of plants selected randomly from ach plot. Three observations were recorded at 10- day's intervals. Individual selected plants were tagged and divided in to the bottom, middle and top leaves and sheath (5-7) from each portion were recorded the symptoms graded as per the rating scale 1 to 5 (Ahuja and Payak (1978) as:1.0=Disease on one leaf sheath only; few small, non-coalescent lesions present(Highly Resistant) $2.0=$ Disease up to four sheaths; lesions many and always coalescent (Moderately Resistance)3.0 = Disease on all sheaths except two internodes below the ear(Tolerant) $4.0=$ Disease up to the internode bearing the ear shoot but shank not affected(Susceptible)5.0=In addition to disease rating symptoms of 4.5, shrinkage of stalk; reduced ear dimensions, wet rot and 
disorganization of ear; kernel formation absent or rudimentary; prematurely dead plants common; abundant sclerotial production on husk leaves, kernels, ear tips and stalk fibres (Highly Susceptible).Yield data $(\mathrm{Kg} / \mathrm{ha})$ and 100 grain weight $(\mathrm{g})$ were further used for calculating of PDI ( Per cent disease index).

\section{Results and Discussion}

Bio efficacy of systemic fungicides on Rhizoctonia solani in in- vitro

The data given in (Table 1 and 2) revealed that all the four fungicides were found significantly superior over check by inhibiting the radial growth of test pathogen.

Among systemic fungicides, difenoconazole 25EC was found the most effective followed by validamycin $3 \mathrm{SL}$, thiophanate methyl 70 WP and hexaconazole 5\% EC. Difenoconazole 25EC, thiophanate methyl 70 WP were completely inhibited of radial growth is $100 \%$ at 10 and validamycin at 15 ppm concentrations, respectively.

Among non-systemic mancozeb 75WPwas found the most effective followed by fungicides captaf $50 \mathrm{WP}$, chlorothalonil 75 WP and zineb 75 WP. Mancozeb 75WPwas completely inhibited of radial grow this at 20 ppm concentration.

Apparently it is evident that all the systemic fungicides were more effective than non systemic fungicides when compared under in vivo conditions. It is also observed under in vitro conditions.

It is also observed that increased in per cent inhibition was invariably proportional to the increase in the concentration of respective fungicides.
Bio efficacy of systemic fungicides on Rhizoctonia solani in in-vivo

The data given in table 3 and 4 revealed that all the treatments significantly decreased disease severity, increased grain yield as compared to control plots.

During 2015-16 and 2016-17 crop season, among systemic fungicides seed treatment with cabendazim at $0.1 \%$ anddifenoconazole 25EC,validamycin 3 SL two prophylactic sprays at 10 - days interval was found superior over the other treatments. Validamycin 3 SL $90.99 \%$ reduction in the disease severity followed by difenoconazole 25ECand hexaconazole $5 \% \mathrm{C}$.

Among systemic fungicides seed treatment with carbendazim $0.1 \%$ and two prophylactic sprays at 10 days interval was found superior over the other treatments giving validamycin reduction in disease severity followed by difenoconozole $25 \mathrm{EC}$, hexaconazole 5 EC and thiophanate methyl 75 WP. Maximum increase in grain yields $27500 \mathrm{Kg} / \mathrm{ha}$ with validamycin 3 SL @ 0.2 followed by difenoconazole $25 \mathrm{EC}, 2366 \mathrm{Kg} / \mathrm{ha}$ with two years polled data.

Among non systemic fungicides seed treatment with captan and two prophylactic sprays at 10 - days intervalzineb $75 \mathrm{WP}$ was found superior over the other treatments giving 99.30 per cent reduction in disease severity. Mancozeb75 WP which was similar to chlorothalonil $75 \mathrm{WP}$ followed bycaptaf 50 WP. Maximum increase in grain yield with mancozeb $75 \mathrm{WP} 2133 \mathrm{Kg} / \mathrm{ha}$ was recorded and chlorothalonil $75 \mathrm{WP} 2083 \mathrm{Kg} / \mathrm{ha}$ were followed by zineb $75 \mathrm{WP} 1933 \mathrm{Kg} / \mathrm{ha}$ and captaf $50 \mathrm{WP} 1833 \mathrm{Kg} / \mathrm{ha}$ during 2015 and 2016. 
Table.1 Bio efficacy of systemic fungicides against Rhizoctonia solaniin in-vitro

\begin{tabular}{|c|c|c|c|c|c|c|c|c|c|c|}
\hline \multirow[t]{2}{*}{ Fungicide } & \multicolumn{5}{|c|}{ Radial growth (mm) } & \multicolumn{5}{|c|}{ Per cent inhibition of mycelial growth (mm) } \\
\hline & $\begin{array}{c}10 \\
\text { ppm }\end{array}$ & $\begin{array}{c}15 \\
\text { ppm }\end{array}$ & $\begin{array}{c}20 \\
\mathrm{ppm}\end{array}$ & $\begin{array}{c}25 \\
\mathrm{ppm}\end{array}$ & Mean & $\begin{array}{c}10 \\
\text { ppm }\end{array}$ & $\begin{array}{c}15 \\
\text { ppm }\end{array}$ & $\begin{array}{c}20 \\
\text { ppm }\end{array}$ & $\begin{array}{c}25 \\
\mathrm{ppm}\end{array}$ & Mean \\
\hline Thiophanate methyl 70 WP & 0.0 & 5.00 & 10.0 & 15.0 & 7.5 & 100.0 & 95.0 & 90.0 & 85.0 & 92.5 \\
\hline Difenoconazole 25EC & 0.0 & 0.0 & 0.0 & 0.0 & 0.0 & 100.0 & 100.0 & 100.0 & 100.0 & 100.0 \\
\hline Hexaconazole $5 \%$ EC & 5.0 & 10.0 & 15.0 & 20.0 & 12.0 & 95.0 & 90.0 & 85.0 & 80.0 & 87.5 \\
\hline Validamycin 3 SL & 0.1 & 0.1 & 0.1 & 0.0 & 0.5 & 99.5 & 99.9 & 99.8 & 99.8 & 99.8 \\
\hline Control & 90.0 & 90.0 & 90.0 & 90.0 & 90.0 & - & - & - & - & - \\
\hline $\operatorname{Sem} \pm$ & 0.22 & 0.43 & 0.48 & 0.81 & 1.72 & & & & & \\
\hline $\mathrm{CD}^{-}$ & 0.64 & 1.27 & 1.44 & 2.40 & 5.24 & & & & & \\
\hline
\end{tabular}

Table.2 Bio efficacy of non-systemic fungicides against Rhizoctonia solani in in-vitro

\begin{tabular}{|c|c|c|c|c|c|c|c|c|c|c|}
\hline \multirow[t]{2}{*}{ Fungicide } & \multicolumn{5}{|c|}{ Radial growth (mm) } & \multicolumn{5}{|c|}{$\begin{array}{l}\text { Per cent inhibition of mycelial } \\
\text { growth }(\mathrm{mm})\end{array}$} \\
\hline & $\begin{array}{l}100 \\
\mathrm{ppm}\end{array}$ & $\begin{array}{l}200 \\
\mathrm{ppm}\end{array}$ & $\begin{array}{l}300 \\
\mathrm{ppm}\end{array}$ & $\begin{array}{l}400 \\
\text { ppm }\end{array}$ & Mean & $\begin{array}{l}100 \\
\mathrm{ppm}\end{array}$ & $\begin{array}{l}200 \\
\mathrm{ppm}\end{array}$ & $\begin{array}{l}300 \\
\mathrm{ppm}\end{array}$ & $\begin{array}{l}400 \mathrm{p} \\
\mathrm{pm}\end{array}$ & $\begin{array}{l}\text { Mea } \\
\mathrm{n}\end{array}$ \\
\hline Mancozeb 75WP & 0.1 & 0.2 & 0.3 & 0.4 & 0.2 & 99.0 & 99.8 & 99.7 & 99.6 & 99.5 \\
\hline Chlorothalonil 75 WP & 5.0 & 10.0 & 15.0 & 20.0 & 12.5 & 95.0 & 90.0 & 85.0 & 80.0 & 87.5 \\
\hline Zineb 75 WP & 5.0 & 15.0 & 20.0 & 10.0 & 87.5 & 95.0 & 85.0 & 80.0 & 90.0 & 87.5 \\
\hline Captaf 50 WP & 5.0 & 6.0 & 7.0 & 9.00 & 93.2 & 95.0 & 94.0 & 93.0 & 91.0 & 93.2 \\
\hline Control & 90.0 & 90.0 & 90.0 & 90.0 & 90.0 & - & - & - & - & - \\
\hline Sem \pm & 0.55 & 0.92 & 0.87 & 1.83 & 1.88 & & & & & \\
\hline $\mathrm{CD}^{-}$ & 1.63 & 2.73 & 2.59 & 5.45 & 5.58 & & & & & \\
\hline
\end{tabular}


Table.3 Bio efficacy of systemic fungicides against Rhizoctonia solaniin in-vivo

\begin{tabular}{|l|c|c|c|c|c|c|}
\hline \multirow{2}{*}{ Fungicide } & \multicolumn{3}{|c|}{ Mean } \\
\cline { 2 - 7 } & \multicolumn{3}{|c|}{ PDI } & \multicolumn{3}{c|}{ Yield (q/ha) } \\
\hline Thiophanate methyl 70 WP @ 0.1\% & $2016-17$ & $2017-18$ & Polled & $2016-17$ & $2017-18$ & Polled \\
\hline Difenoconazole 25EC @ 0.15 \% & 18.0 & 16.0 & & 28.3 & 15.3 & $\mathbf{2 1 . 8}$ \\
\hline Hexaconazole 5\% EC @ 0.2 \% & 10.0 & 9.0 & & 22.0 & 25.3 & $\mathbf{2 3 . 6}$ \\
\hline Validamycin 3 SL @ 0.2 \% & 12.0 & 10.0 & & 21.0 & 26.0 & $\mathbf{2 3 . 5}$ \\
\hline Control & 10.0 & 8.0 & & 26.6 & 28.3 & $\mathbf{2 7 . 5}$ \\
\hline Mean & 59.0 & 64.0 & & 24.3 & 14.0 & $\mathbf{1 9 . 1}$ \\
\hline Sem \pm & $\mathbf{2 1 . 8 0}$ & $\mathbf{2 1 . 4 0}$ & - & $\mathbf{2 4 . 4}$ & $\mathbf{2 1 . 8}$ & - \\
\hline CD & 0.85 & 1.34 & & 1.74 & 2.22 & \\
\hline CD for Seasons & 2.56 & 4.04 & & 5.22 & 6.69 & \\
\hline CD for Treatments & & & 0.42 & & & 2.20 \\
\hline CD for Season X Treatments & & & 0.49 & & & 1.99 \\
\hline
\end{tabular}

Table.4 Bio efficacy of non-systemic fungicides against Rhizoctonia solani in in-vivo

\begin{tabular}{|l|c|c|c|c|c|c|}
\hline \multirow{2}{*}{ Fungicide } & \multicolumn{5}{|c|}{ Mean } \\
\cline { 2 - 7 } & Disease score compared to control & \multicolumn{3}{c|}{ Yield (q/ha) } \\
\cline { 2 - 8 } & $2016-17$ & $2017-18$ & Polled & $2016-17$ & $2017-18$ & Polled \\
\hline mancozeb 75WP @ 0.3 \% & 48.0 & 39.0 & & 24.0 & 18.6 & $\mathbf{2 1 . 3}$ \\
\hline Chlorothalonil 75WP@ .15\% & 40.0 & 37.0 & & 25.0 & 16.6 & $\mathbf{2 0 . 8}$ \\
\hline zineb 75 WP @ @ 0.1 \% & 42.0 & 40.0 & & 22.0 & 16.6 & $\mathbf{1 9 . 3}$ \\
\hline captaf 50 WP @ 0.25 \% & 40.0 & 36.0 & & 19.6 & 17.0 & $\mathbf{1 8 . 3}$ \\
\hline control & 69.0 & 74.0 & & 17.6 & 16.6 & $\mathbf{1 7 . 6}$ \\
\hline Mean & $\mathbf{4 7 . 8 0}$ & $\mathbf{4 5 . 2 0}$ & & $\mathbf{2 1 . 6 7}$ & $\mathbf{1 7 . 1 3}$ & - \\
\hline Sem士 & 2.97 & 3.16 & & 1.42 & 1.36 & \\
\hline CD & 8.94 & 9.53 & & 4.27 & 4.08 & \\
\hline CD for Seasons & & & 0.61 & & & 2.08 \\
\hline CD for Treatments & & & 0.44 & & & 2.79 \\
\hline CD for Season X Treatments & & & 0.62 & & & 3.95 \\
\hline
\end{tabular}


The 'control' consisted of spray application of water only. The trial was sown in randomized block design in which row to row distance was $75 \mathrm{~cm}$ and plant distance was $25 \mathrm{~cm}$. The pathogen was multiplied on maize grains and inoculations were carried out by inserting four such grains (25-d old culture) between the rinds and the enclosing sheaths at second or third basal internode of 30 days old test plant. In all, two spray applications of the chemicals, first after two days of inoculation followed by the second after 15 days, were made.

Observations on intensity of the disease were recorded after 45 days of inoculation following 1-5scale devised by Ahuja and Payak (1983). Intermediate ratings were also recorded and the mean of 50inoculated plants were calculated.

Harvesting was done as soon as the huskcovers turned brown and the silks became completely dry. Yield of grain wt. at $15 \%$ grain moisture after shelling was presented in $\mathrm{q} /$ haafter thorough drying in the sun.

Several other workers also reported the bio efficacy of fungicides in maize as well as in other crops like urd bean, ground nut, cowpea, mung, rice, bean (Santosh et al., (2014),

It can be concluded that application of 10 ppm concentration difenoconazole 25EC, validamycin $3 \mathrm{SL}$, thiophanate methyl $75 \mathrm{WP}$ completely checked the growth of the fungus Based on bio efficacy of fungicides in vitro, they were further tested under in vivo conditions. Validamycin 3 SL @ $0.2 \%$ was applied as foliar spray showed lowest disease severity, highest grain yield $27500 \mathrm{Kg} / \mathrm{haas}$ followed by difenoconozole $25 \mathrm{EC}$, hexaconazole $5 \mathrm{EC}$ and thiophanate methyl 75 WP $0.15 \%, 0.2 \%$ and 0.1 per cent.

\section{References}

Ahuja, S.c. and Payak, M.M. (1992). Symptoms and signs of banded leaf and sheath blight of maize. Phytoparasitica 10: 41-49.

Ahuja, S.C. and Payak, M.M. (1983). A rating scale for banded leaf and sheath blight of maize. Indian Phytopath. 36: 338340.

Ahuja, S.C. and Payak, M.M. (1978). A field inoculation technique for evaluating maize germplasm to BLSB. Indian Phytophath. 31: 517520.

Lal, S., Butchaiah, K. and Baruah, P. (1985). Comparative efficacy of some fungicides and antibiotics in control of banded sclerotial disease of maize. Pesticides 19(2): 17-19.

Santosh Kumar, Tripathi, H.S and Singh, D1 (2014). Evaluation of selected systemic and non systemic fungicides in vitro and in vivo condition against Web blight disease of urdban caused by Rhizoctonia solani Kühn.

Vincent J.M. (1947) Nature, 159, 850.

\section{How to cite this article:}

Bolla Venkateswarlu and Surja Kanta Beura. 2020. Bio efficacy of Selected Systemic and Non Systemic Fungicides invitro and invivo Condition against Banded Leaf and Sheath Blight Disease of Maize caused by Rhizoctonia solani Kühn. Int.J.Curr.Microbiol.App.Sci. 9(07): 2069-2074. doi: https://doi.org/10.20546/ijcmas.2020.907.239 